\title{
Russian Federation: Technical Note on Crisis Management and Crisis Preparedness Frameworks
}

This paper was completed in June 2011, based on the information received as of April 2011. The views expressed in this document are those of the staff team and do not necessarily reflect the views of the government of the Russian Federation or the Executive Board of the IMF.

The policy of publication of staff reports and other documents by the IMF allows for the deletion of market-sensitive information.

Copies of this report are available to the public from

International Monetary Fund • Publication Services

700 19th Street, N.W. • Washington, D.C. 20431

Telephone: (202) 623-7430 • Telefax: (202) 623-7201

E-mail: publications@imf.org • Internet: http://www.imf.org

\section{International Monetary Fund Washington, D.C.}




\title{
FinANCIAL SECTOR ASSESSMENT PROGRAM STABILITY MODULE \\ RUSSIAN FEDERATION
}

\section{CRISIS MANAGEMENT AND CRISIS PREPAREDNESS FRAMEWORKS}

TECHNICAL NoTE

\author{
JUNE $2011^{1}$
}

INTERNATIONAL MONETARY FUND

MONETARY AND CAPITAL MARKETS DEPARTMENT

LEGAL DEPARTMENT

\footnotetext{
${ }^{1}$ This note was prepared on the basis of information received as of April 2011.
} 


\section{Contents}

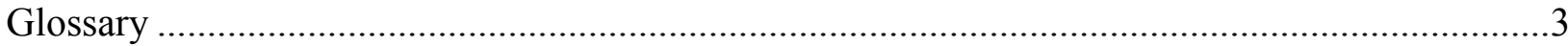

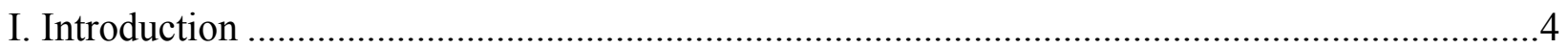

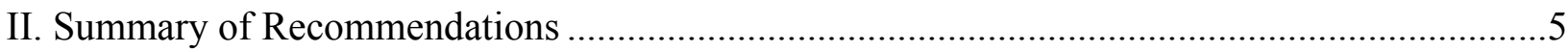

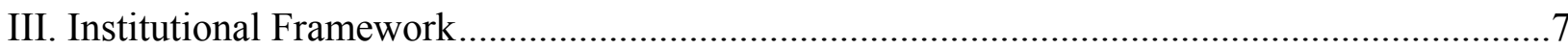

A. Institutional Framework and Coordination Arrangements for Systemic Risk

Monitoring and Crisis Management .............................................................................

B. Macroprudential Policy ............................................................................................

C. Inter-Agency Coordination and Exchange of Information ..........................................12

IV. Supervisory Early Intervention of Problem Banks ..................................................................13

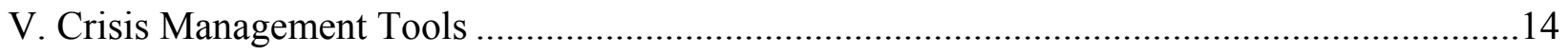

A. Official Financial Support.......................................................................................14

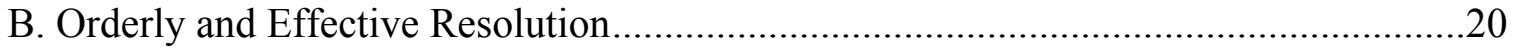

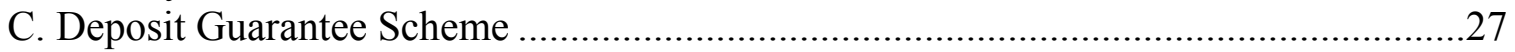

VI. Legal Protection ........................................................................................................... 31

Appendices

I. An Illustrative Example of a Prompt Remedial Action Framework ………………...................34

II. Timeline of Crisis Related Policy Measures ...............................................................................35

Text Box:

1. Developing a Permanent Resolution Regime for Russia..........................................................23 


\section{GLOSSARY}

AM Law Law on Additional Measures to Strengthen the Stability of the Banking System through December 31, 2011

BCP Basel Core Principles

BLaw Banking Law

CAR Capital adequacy ratio

CBR Central Bank of Russia

CBR Law Law on the Central Bank of the Russian Federation

DI

Deposit insurance

DIA

Deposit Insurance Agency

DI Law Law on Insurance of Household Deposits in Banks of the

Russian Federation

ELA Emergency liquidity assistance

ILaw Law on Insolvency (Bankruptcy) of Credit Institutions

FSFM Federal Service for Financial Markets

FSIS Federal Service of Insurance Supervision

MoU Memorandum of Understanding

MoF Ministry of Finance

OBA Open bank assistance

P\&A Purchase and assumption

RRP Recovery and resolution plan

SIFI Systemically important financial institution 


\section{INTRODUCTION}

\section{The financial crisis in Russia in $\mathbf{2 0 0 8}$ was partly triggered by global} developments but its causes were domestic in origin. Domestic bank credit to the corporate and household sectors rose at an unsustainable level of approximately 400 percent over the four years prior to the crisis. Fueled by rising property and commodity prices, Russian bank lending was increasingly financed by external borrowing and concentrated on the real estate and construction sectors.

2. The interbank lending market froze in the fall of 2008. A flight to quality following the collapse of Lehman Brothers sharply reversed external financing and triggered large losses on the Russian stock and corporate bond markets. Banks incurred immediate losses on their marketable securities and were exposed to falling property prices, through collateral on loans to the real estate, construction and household sectors. During the global crisis, interbank lending froze even in countries with deep and liquid interbank markets. In Russia's segmented market, where access to unsecured interbank funding is limited for all but the top fifteen banks in normal times, a system wide liquidity crisis developed.

3. Depositor confidence in the banks was severely undermined. ${ }^{2}$ The spiraling fall in assets prices and the liquidity crunch undermined consumer confidence in the banking sector and a run on deposits ensued. Approximately 8.6 percent of deposits were withdrawn from August to November 2008, exacerbating the liquidity problems at the banks.

\section{As in other countries, the authorities initially lacked adequate tools to deal with} the crisis but adopted a broad range of measures which ultimately stabilized the banking system. The key measures directly targeting the banking sector included: ${ }^{3}$

- $\quad$ Recapitalizing banks: The Government and the CBR recapitalized three state owned banks (Vnesheconombank (VEB), Vneshtorgbank (VTB) and Sberbank). VEB was then used as a vehicle for recapitalizing other banks by providing subordinated loans to VTB bank, Rosselkhozbank and fifteen other banks. The State Mortgage Agency (AHML) was also recapitalized to strengthen its capacity to purchase mortgage portfolios from banks, and provide support to the mortgage market. These capital injections amounted to Rub 1409 billion. In addition, the Government announced Rub 300 billion of guarantees of bank loans to key non-financial corporations.

\footnotetext{
${ }^{2}$ Recollection of bank failures and depositor losses which occurred during the 1998 crisis likely played a role.

${ }^{3}$ Detailed crisis measures and their current status (where available) are set out in Appendix II.A range of other measures primarily directed at the corporate sector also provided indirect benefit to the banks. These included VEB buying Russian stocks and shares and refinancing the external debt of Russian corporations (up to $\$ 50$ bn) and CBR intervention which slowed the depreciation of the Ruble, reducing the foreign currency losses of Russian corporations.
} 
- Liquidity provision: A wide range of measures were adopted including temporarily lowering required liquidity reserve ratios, widening access to the CBR's refinancing facilities (including extending eligible collateral to include corporate bonds), auctioning government deposits, extending unsecured loans from the CBR to banks with a minimum credit rating, and guarantees by the CBR of interbank loans.

- Safety net and bank resolution powers: The coverage on insured deposits was increased from Rub 400,000 (approximately $\$ 15,700$ ) to Rub 700,000 (approximately $\$ 27,500$ ). The CBR and DIA were given official powers to resolve failing banks of systemic importance including funding new investors, recapitalizing/nationalizing banks, and transferring assets and liabilities to third parties (also known as P\&A) powers. These powers gave the authorities a broad mandate on a temporary basis and were used by the DIA to deal with eighteen failing systemic banks and were funded by a grant from the Government and loans from the CBR.

5. This technical note discusses the lessons learnt from the crisis and makes a number of recommendations for strengthening the crisis management regime. This note is structured as follows: Chapter II summarizes our key findings and recommendations; Chapter III analyses the institutional framework and coordination arrangements for systemic risk monitoring and crisis management; Chapter IV assesses crisis prevention measures including the approaches to intervene with potential problem institutions at an early stage; Chapter V covers crisis management tools and Chapter VI deals with legal protection.

\section{SUMmaRY OF RECOMMENDATIONS}

\section{The authorities responded with a comprehensive range of measures that} ultimately mitigated the shock of the banking crisis. Two key questions arise going forward: (i) how to minimize the risk of banking crises recurring in the future; and (ii) how to address moral hazard which (as in other countries) increased following the extensive state intervention to resolve the crisis.

7. Intra-agency cooperation was initially ad hoc and needs strengthening. Clear mandates should be assigned which allocate consistent policy objectives, functions, instruments and powers for each authority. The working group of the MoF may be the appropriate vehicle for coordination but it needs clear objectives for financial stability and crisis preparedness and should include the DIA.

8. Enhancing micro-prudential supervision is a priority, but this alone may not be sufficient. The CBR should also develop a set of macroprudential tools, and governance arrangements for deploying them, to reduce the risk of system wide imbalances developing in the future - e.g., the rapid growth in bank lending (before the latest crisis) or the build-up in foreign currency exposures on bank balances sheets (leading up to both of the last crises). 
9. Early identification of problem banks and prompt remedial action is important to mitigate moral hazard risks post crisis. Currently, there are a range of measures set out in different pieces of legislation which have prompt remedial action like features. These include the freeze on deposit taking after two quarters of losses by any bank and the mandatory revocation of banking license if CAR falls below two percent. A transparent scale of actions at pre-determined triggers would make it clear in advance to shareholders and managers the consequences of not taking remedial measures. The authorities should adopt a transparent regime for supervisory action with a clearly delineated set of increasingly demanding mandatory (plus discretionary) measures as a bank's regulatory position deteriorates.

10. The authorities should adopt a permanent bank resolution regime combined with early intervention powers for the CBR and DIA. We recommend that this includes:

- Official administration. The CBR should be able to appoint the DIA as an official administrator at a sufficiently early stage for all banks, not just systemic ones, when certain quantitative or qualitative triggers are met, e.g., capital falls below a fixed percentage of required CAR; if there is a threat to financial stability; if the bank is or is likely to become insolvent, is engaging in unsafe/unsound practice, there is a threat to interests of depositors/creditors, etc... The existing provisions in the ILaw, the CBR Law, the BLaw and the proposed legislation making the official powers under the AM Law permanent should be streamlined into a single piece of legislation empowering the DIA as official administrator with a range of powers, including the ability to undertake a purchase and assumption transaction.

- Stringent systemic risk test and protection for deposit insurance fund. The decision on which official administration tool to deploy, or whether instead to liquidate the bank and pay out insured deposits should be taken on a least-cost basis. To mitigate the risks of moral hazard, OBA tools such as loans to purchasers and investors, capital injections, or nationalization should be restricted to only those cases that pose a grave systemic threat, with a clear process that entails a decision taken at a very high level by the authorities. Furthermore, in such circumstances, management who were responsible for the failure of the bank should be removed and the contribution of the deposit insurance fund should be limited to what it would have incurred in liquidation, with the remainder of the funds having to be provided by the government.

- Early warning. As needed to fulfill the official administrator powers, the DIA should be given more advanced notice before a license is revoked by the CBR, as well as the powers to conduct an audit of problem banks jointly with the CBR. A "watch-list" of problem banks should be created, with banks assigned to the list based upon pre-agreed criteria. The DIA should be notified by the CBR of any banks which are placed, or which are reviewed for potential placement, on the list. 


\section{INSTITUTIONAL FRAMEWORK}

11. A sound institutional framework for crisis management and bank resolution requires clear and effective legal underpinnings both within each institution's legal framework, as well as among the relevant institutions. For example, each institution should have a strong and clear mandate. In addition, there should be an adequate allocation of labor across the institutions and explicit coordination mechanisms between the institutions, including solid legal bases for the exchange of confidential information in times of distress.

\section{A. Institutional Framework and Coordination Arrangements for Systemic Risk Monitoring and Crisis Management}

12. The legal framework in Russia does not assign explicit responsibility to any agency for overall financial stability and systemic risk monitoring. The powers and responsibilities of the key institutions can be summarized as follows:

- $\quad$ The $\mathbf{M o F}$ is the federal agency responsible for drafting and implementing national policy and legal regulation for the financial markets and this includes the areas of budget, taxation, insurance, currency, banking, government spending, auditing, accounting and financial statements.

- $\quad$ The $\mathbf{C B R}$ is the microprudential regulator, responsible for the regulation and supervision of banks. ${ }^{4}$ The functions and objectives of the CBR are set out in the CBR $\mathrm{Law}^{5}$ and its principle objectives are to maintain stability of the Russian banking system (which is key to financial stability) and protect interests of depositors and creditors.

- The DIA is a state corporation established by the Russian Federation to manage the operations of the mandatory deposit insurance system. ${ }^{6}$ In October 2008, the DIA was given additional temporary powers ${ }^{7}$ to implement measures to prevent bankruptcies of banks which are members of the mandatory deposit insurance system, for the purposes of maintaining stability in the banking system and protecting legitimate interests of bank depositors and creditors.

- $\quad$ The FFSM is a federal executive body responsible for the regulation and supervision of financial markets (except for banking and auditor activity). In March 2011, supervision of the insurance sector was subsumed under the FSFM and the FSIS became part of the

\footnotetext{
${ }^{4}$ CBR Law Art 56

${ }^{5}$ CBR Law Arts $3 \& 4$

${ }^{6}$ DI Law Art 14

${ }^{7}$ AM Law Art 1, powers through 31 December 2011
} 
FSFM. $^{8}$ The integration of the insurance supervisor into the FSFM is at its early stages and the government is currently drafting a resolution to clarify the operational aspects of the new agency.

13. Despite the absence of assigned responsibility for financial stability or formalized arrangements, the Russian authorities ultimately cooperated effectively in responding to the crisis. Due to the dominance of the banking sector in the financial system, the lion's share of responsibility resided with the CBR. During the crisis, the MoF and the CBR played an important and appropriate role in coordinating crisis management, with regular meetings held with the other agencies.

\section{Commendable steps have been taken recently to strengthen systemic monitoring and crisis coordination.}

- In December 2010, an Inter-Agency working group under the Presidential Council (Working Group to Monitor Financial Market Conditions) was created. The working group is headed by the Deputy Minister of Finance and its members include representatives from MoF, Ministry of Economic Development, CBR, FSFM, Federal Antimonopoly Service, Federal Service for Financial Monitoring, PricewaterhouseCoopers Audit and the Presidential Administration. The mission had not fully sighted the objectives and mandate of the working group but understands that it was created to identify mechanisms to monitor the state of the financial market of the Russian Federation and SIFIs and propose the legal amendments needed for the establishment of these mechanisms

- In March 2011, the CBR established a Financial Stability Directorate, which is expected to carry out monitoring of emerging risks not only in the banking sector but also arising from emerging trends and products in other sectors.

\section{Nevertheless, further efforts should be taken to make the systemic risk} monitoring and crisis coordination framework effective. It is still early to assess the effectiveness of the working group, but if the intent of the working group is to establish an effective vehicle for macroprudential coordination, the working group should:

- $\quad$ Agree on a road map for crisis management, including having clarity on the individual roles and responsibilities for each agency. ${ }^{9}$ In this regard, the mandate vested upon each agency would need to be taken into account;

- Meet regularly (e.g., quarterly or more frequently as needed) to assess systemic risks and to formulate plans and strategies to address them;

\footnotetext{
${ }^{8}$ Presidential Decree of March 4, 2011 N 270 "On measures to improve government regulation of the financial market of the Russian Federation"

${ }^{9}$ The authorities may also wish to make public the agreed roles and responsibilities of the individual agency.
} 
- Be made responsible for crisis planning and preparedness, including undertaking simulations, etc.;

- Ensure that all legal and operational hurdles for information exchange among participants are cleared. ${ }^{10}$

16. The DIA is noticeably absent from this working group and its interaction is via the CBR only. The DI Law provides that the DIA and the CBR shall coordinate their activities and inform each other on issues related to execution of deposit insurance actions. ${ }^{11}$ Issues relating to a bank's stability are also discussed at the DIA Board of Directors meetings, where representatives from the MoF, Ministry of Economic Development and CBR are represented on the board. ${ }^{12}$ As any multipartite high-level group should include all relevant agencies, the mission recommends that the DIA should be included in this interagency working group, particularly as the DIA is intended to be given permanent powers to resolve banks in a systemic crisis situation.

\section{The inclusion of PricewaterhouseCoopers Audit in this working group could be}

further clarified. It is unclear why a private sector entity is included in a working group for systemic risk monitoring and crisis coordination (assuming that is the intent of this working group), which in other countries typically involve only public sector agencies. As a systemic risk monitoring and crisis coordination working group may deal with market sensitive issues involving banks, the mission suggests that private sector entities be excluded. The inclusion of a private sector entity may raise concerns on access to confidential information or the type of information that can be shared freely within the working group. There could also be potential conflict of interest issues in relation to the private sector entity's business dealings with banks, etc.

\section{B. Macroprudential Policy}

\section{The objective of macroprudential policy is to limit systemic financial risk. ${ }^{13}$}

Russia has suffered two systemic financial crises in the last decade. The causes of the 1998 and 2008 crises were very different; the former was primarily driven by fiscal instability and sovereign default and the latter was a classic bank lending boom followed by bust. However, there were some shared characteristics including the build-up in foreign currency exposures

\footnotetext{
${ }^{10}$ In this aspect, a very positive first step is the content of draft legislation on consolidated supervision and information sharing which removes banking secrecy restrictions.

${ }^{11}$ DI Law Art 27(2)

${ }^{12}$ DI Law Art 42

${ }^{13}$ For a workable definition of systemic risk and systemically important institutions see International Monetary Fund, Bank of International Settlements, Financial Stability Board, 2009, "Guidance to Assess the Systemic Importance of Financial Institutions, Instruments, and Markets: Initial Considerations," Report to the G-20 Finance Ministers and Governors (October).
} 
on banks' balances sheets, the lack of visibility of bank lending to related counterparties and concentrated exposures, high reported capital ratios leading up to the crisis which in many cases subsequently proved to be overstated. The risk of credit bubbles developing in the future in Russia may be exacerbated by a number of specific factors including:

- The relatively low penetration of the financial system - the Russian financial system accounts for only 80 percent of GDP, suggesting further growth as the system matures;

- The importance of the resources sector in the Russian economy which may exacerbate economic cycles as a result of fluctuations in mineral prices;

- Proposals to promote Russia as an international financial centre, with the intention to develop internationally active banks requiring a certain size and complexity to provide a full range of services to large Russian companies.

\section{Given the exposure of the Russian financial sector to significant}

macroeconomic and commodity price volatility, systemic risk can build up quickly. It is thus important that the authorities develop a macroprudential framework capable of identifying and addressing systemic imbalances before they materialize. It must be noted, however, that macroprudential policy does not replace sound prudential supervision or appropriate macroeconomic policies.

\section{The CBR has already been taking steps in this direction.}

- It has been carrying out stress tests in the banking sector since 2003, and publishes the main results on its website. After 2006, such stress tests were carried out twice a year, but the frequency increased to quarterly (October 2008) and then monthly (2009) in the peak of the crisis. The stress tests are top-down, with a unified shock being applied to the balance sheets of all banks, affecting credit, market and liquidity risk. The stress tests then consider a crisis in the interbank market and interconnectedness effects. ${ }^{14}$ The results are used to check resilience of the individual banks and orient supervision, but also to monitor systemic stability. There are non-public reports that are shared with the government and bring risk-warnings and rankings of risk-warnings, with severity grading.

- The newly created Financial Stability Directorate in the CBR intends to combine already existing stress testing efforts with information provided by the settlements and payment system department. The Directorate plans to function as an alert mechanism and coordination venue for macroprudential action by the CBR - in that sense it is very positive that the Director has a seat on both the Supervision Committee and in the Monetary Policy Committee.

\footnotetext{
${ }^{14}$ Staff in the newly created Financial Stability Directorate of the CBR reported that they plan to extend topdown stress tests to non-bank institutions which may present a systemic risk.
} 
- $\quad$ The CBR has already used some instruments in the macroprudential toolkit. ${ }^{15}$ It used differentiated reserve requirements for obligations denominated in foreign currency and non-residents (introduced in 2007 and reversed in 2008), and sought to implement an interest rate policy aimed at "mitigating the risk of a sudden capital outflow." ${ }^{16}$ It also lowered provisioning standards during the crisis to act against the cycle and stimulate credit in the downturn, and imposed limits on net open foreign exchange positions. It has also proposed legislation outside its mandate with a view to promoting financial stability - for instance, an amendment to the Tax Code to make foreign currency denominated borrowings less attractive to financial and non-financial companies. ${ }^{17}$

\section{Given the systemic importance of the banking sector and the synergies of an} agency that unites monetary policy and supervision, the CBR should continue playing a leading role in developing macroprudential tools. Consideration should be given to the appropriate governance structure ${ }^{18}$ within the $\mathrm{CBR}$, and the tools that would be appropriate in the Russian context should be identified. Although there is no international consensus on macroprudential tools, options under consideration include: ${ }^{19}$

- $\quad$ countercyclical capital buffers under Basel III;

- $\quad$ time-varying LTV, debt-to-income (DTI) and loan-to-income (LTI) caps;

- $\quad$ time-varying limits on currency mismatches;

- $\quad$ time-varying limits on loan-to-deposit ratios;

- $\quad$ time-varying caps and limits on exposure or credit growth (e.g. to real estate);

- $\quad$ time varying leverage limits; or

- $\quad$ regulatory policies for SIFIs to increase loss absorption capacity and intensified supervision.

\footnotetext{
${ }^{15}$ Macroprudential instruments and frameworks: a stocktaking of issues and experiences, CGFS Publications No. 38, May 2010.

${ }^{16}$ According to CBR, at the height of crisis in 2008 rates were raised to curb outflows, while cuts in 2009 and 2010 aimed at slowing the appreciation of the currency.

${ }^{17}$ Amendment to Article 269 of Part II of the tax code.

${ }^{18}$ Macroprudential policy is an evolving issue. To be effective, institutional arrangements need to ensure the policymaker's ability and willingness to act, and for both monetary and macroprudential policies, political economy considerations favor strong operational independence from the political process. One institution which has taken concrete steps and set up a formal governance structure is the Bank of England which has been tasked by the UK government with establishing an independent Financial Policy Committee, founded on similar lines to the Monetary Policy Committee to implement and be held accountable for macroprudential policy. For more information see paragraphs 1.10-1.12 of: http://hm-treasury.gov.uk/d/consult_financial_regulation_condoc.pdf.

${ }^{19}$ For comprehensive reviews of macroprudential instruments, see BIS papers Macroprudential policy tools and frameworks, Update to G20 Finance Ministers and Central Bank Governors, March 14, 2011, and Macroprudential policy - a literature review, February 2011.
} 


\section{Inter-Agency Coordination and Exchange of Information}

\section{Inter-agency MoUs are useful for inter-agency coordination and information} sharing as they provide a clear framework. During the crisis, the experience in Russia appears to be that while some MoUs exist, they proved ineffective. This was also the experience in other countries ${ }^{20}$ but was exacerbated in the case of Russia due to the legal restrictions to the scope and type of information that can be shared.

\section{With lessons learnt from the crisis, the CBR is in the process of reviewing its} MoUs with other agencies. Prior to the merger of the FSFM and the FSIS, the CBR was in the process of concluding a MoU with the FSFM. With the merger, the CBR and the FSFM will need to revisit the MoU with the FSIS to ensure that there is in place a MoU between the CBR and the FSFM for information sharing with regard to the regulation and supervision of the financial markets, banking and insurance markets.

\section{Further steps can also be taken to improve communication lines and inter- agency coordination.}

- Russian legislation allows the CBR to share information with other domestic agencies such as the DIA ${ }^{21}$. While the coordination arrangements between the CBR and DIA during the crisis appear to have been successful, there is room to improve the prompt communication of information as well as the earlier involvement of the DIA in the bank resolution process. Access to earlier information regarding a problem bank would aid in the diagnostic process in relation to the DIA's role as an official administrator and enable it to better prepare for a P\&A transaction for example. As such, it is recommended that the MoU between the CBR and the DIA be revisited and there be express legislation which requires the CBR to provide information to the DIA at an earlier stage. Employees of the various agencies should be subject to confidentiality requirements.

- Neither the CBR nor the DIA have MoUs with the MoF. While in practice, information sharing and coordination appears not to have been an issue, it is recommended that there should be a formal framework for coordination and information sharing in the form of an MoU. Such an MoU would provide a clear basis for the exchange of information as well as clarity on content of information to be exchanged in a crisis situation.

- Further, relevant legislative amendments pending before the Duma to remove restrictions on information sharing (relating to banking secrecy) should be passed quickly so that all necessary information can be shared when required.

\footnotetext{
${ }^{20}$ See IMF, Crisis Management and Resolution: Early Lessons from the Financial Crisis, March 2011. (http://www.imf.org/external/pubs/ft/sdn/2011/sdn1105.pdf)

${ }^{21}$ DI law Art 27.
} 


\section{SUPERVISORY EARLy INTERVENTION OF Problem BANKS}

\section{Early identification of problem banks and prompt remedial action is important} to mitigate increased moral hazard risk. Currently, there is a range of measures set out in different pieces of legislation ${ }^{22}$ that empower the authorities with a wide range of tools in response to violations of laws, rules and regulations. These include the power to impose penalties, issue instructions to eliminate violations, restrict payment of dividends, require a rehabilitation plan, replace management, impose a ban on certain operations, appoint an official administrator to manage the institution and revoke the banking license. ${ }^{23}$ However, given the significant state support provided to the banking sector during the crisis, including through forbearance, a more structured and consolidated corrective action regime would help mitigate moral hazard risk going forward.

\section{The authorities should adopt a transparent regime for supervisory action (a} Prompt Remedial Action framework), with a clearly delineated set of mandatory and discretionary measures as a bank's regulatory situation deteriorates. A transparent scale of mandatory actions at pre-announced triggers would make the consequences of not taking early remedial action clear to shareholders and managers. The features of this regime should include a delineated or stepped scale of mandatory and discretionary penalties and restrictions as a bank falls below certain quantitative thresholds relating to capital and liquidity or qualitative triggers. The latter should include not complying with laws, regulations or directives, engaging in an unsafe or unsound practice or when the interests of depositors are otherwise threatened. This would mandate a consistent approach in the regulatory treatment of different failing banks. An illustration of possible mandatory and discretionary actions based on a quantitative trigger of the CAR falling below a certain level is set out in Appendix I. These are illustrative and would need to be revised for the specific Russian context. ${ }^{24}$

\section{The framework for remedial action should provide for triggers tailored to the}

Russian context. CBR staff have advised that failing banks are frequently proven, following an audit by the CBR, to have significantly less capital than reported due to overstated asset values. This creates a "series break" as banks drop in one step from a CAR above 10 percent to one close to 0 percent. Additional triggers based upon liquidity, which may be more of a leading indicator, would therefore be particularly important in the Russian context. In addition, more automatic use should be made by the CBR of its CAMELS based ratings to

\footnotetext{
${ }^{22}$ CBR Law, BLaw, ILaw and AM Law

${ }^{23}$ CBR Law Arts 72 to 74

${ }^{24}$ This Appendix is for illustrative purposes only; the triggers are too simplistic as presented and should be widened to cover other regulatory minima including core equity and the liquidity ratio, as appropriate for Russia, and aligned to comply with Basel III when it is implemented. Some of these measures currently exist within existing legislation but others would need to be newly introduced.
} 
identify weak banks where closer supervision and audits should be undertaken at an earlier juncture. However, no system of regulatory intervention can be effective if the data which the supervisor relies upon are fraudulent.

\section{Crisis Management Tools}

28. The tools for crisis management and bank resolution should include solid but flexible arrangements for official financial support (emergency liquidity assistance and solvency support) of banks; robust resolution powers for banks as a going concern; a mechanism for orderly liquidation as a gone concern; and a well-designed deposit guarantee scheme.

\section{A. Official Financial Support}

\section{Emergency Liquidity Assistance}

29. The provision of ELA presents a number of challenges for a central bank. It is widely accepted that central banks should provide liquidity to the financial system in the event of a liquidity crisis - for individual banks as well as for the system as a whole. In principle, to guard against moral hazard, this support is to be provided at a penalty interest rate and against good collateral, and the institutions receiving support should be subjected to intensified supervision to ensure that the liquidity shortage did not mask an insolvency problem. However, given the severity of the liquidity shortage in 2008-2009, many central banks expanded their balance sheets considerably by widening the range of acceptable collateral and providing liquidity at non-penalty interest rates to non-financial as well as financial institutions. In many countries, this approach helped limit the potential contagion from the systemic liquidity shortage in late 2008 and early 2009, but it also left the balance sheets of these central banks exposed to more risk, as it avoided the usual safeguards against moral hazard.

30. The ELA from the CBR played a crucial role in preventing the liquidity crisis from undermining the solvency of banks or disrupting the operation of the payments system. Starting in late 2007, the CBR began to ease the conditions for access to central bank liquidity and intensified these efforts following the collapse of Lehman in September 2008. The CBR relied on a variety of options, including expanding existing monetary instruments, introducing new monetary instruments, providing direct financial support to troubled financial institutions, and helping to contain counterparty risk in the interbank market. Specifically, these steps included:

- $\quad$ Ease existing monetary instruments. Starting in September, the CBR began expanded the list of assets useable as collateral on the Lombard list-which eventually included assets with ratings of B-/B3 (down from the pre-crisis standard of $\mathrm{BB} / \mathrm{Ba} 2$ ), nonresident securities, shares and non-marketable assets. It also reduced haircuts on repos and increased the correction factors of the CBR. It began to reduce the required reserve 
ratio, which fell from the pre-crisis level of 4.5 percent for corporate deposits and 4.0 percent for individual deposits to 0.5 percent for both types by mid-2009, and allowed for more reserve averaging. It also lengthened the duration of its open market operations and standing liquidity facilities in stages, reaching a maximum of twelve months by December 2008 .

- Introduce new instruments. In November 2007, the CBR began to accept loans secured by non-marketable assets and guarantees of credit institutions for up to thirty days and then extending the maturity of these loans to three hundred and sixty-five days by January 2009. In October 2008, it began to extend unsecured loans for a maturity of five weeks and then extended the maturity of these loans to 12-months by May 2009.

- Help reduce counterparty risk in the interbank market: In October 2008, the CBR provided a partial guarantee of losses on interbank transactions, if the license of the counterparty was revoked during the crisis.

31. These operations led to a significant increase in gross liquidity provided by the CBR. The stock of liabilities of credit institutions to the CBR rose from Rub 300 billion in June 2008 to a peak of Rub 4.2 trillion (about 10 percent of GDP) in January 2009. During this period, the CBR also reduced its net international reserves by about US\$120 billion to help fund the demand for liquidity in foreign exchange and prevent sharp, uncontrolled depreciation of the ruble vis-à-vis the U.S. dollar and the Euro. As a result the growth in the stock of base money declined sharply in this period, but much of this decline probably reflected a collapse in demand for base money in rubles. By early 2011, the CBR's gross liabilities to credit institutions had fallen to about Rub 500 billion-broadly in line with precrisis levels. As credit institutions scaled back their reliance on this emergency liquidity support, the CBR began to gradually scale back the emergency measures. By mid-2011, the CBR's liquidity facilities will be restored to pre-crisis conditions, except for the loans to Sberbank and the DIA and the placement of deposits in troubled institutions. Also, while no more unsecured loans were granted as of January 2011, this instrument is now a permanent feature of the CBR's toolkit.

32. By early 2011, the interbank market for liquidity had recovered from the effects of the global financial crisis that began in mid-2007. By February 2011, the overnight interbank interest rate had declined to 2.8 percent per annum, well below its peak of 28 percent in late January 2009, and the bid-ask spread had returned to pre-crisis levels. During this period, credit institutions' access to funding from abroad in the form of loans and deposits from non-residents fell from US $\$ 200$ billion before the crisis to US $\$ 150$ billion in early 2011, and at the same time, credit institutions placed more deposits and loans with nonresidents. As a result, since June 2009, credit institutions have been net creditors vis-à-vis non-residents. The segmentation of the interbank market also appears to have eased. The spread between the interbank rate paid by investment grade and non-investment grade banks rose to 9 percent in 2009, as second and third tier banks faced tighter access to interbank 
credit, but by late 2010, this spread had declined to less than 1 percent. Nonetheless, the interbank market was still highly concentrated in the operations of 15 banks, which accounted for 50-60 percent of the market.

\section{The ELA provided by the CBR proved effective, not only in containing the effects of the liquidity crisis but also in several other dimensions:}

- Legitimacy: These measures gained legitimacy by falling clearly under the central bank's mandate to preserve the stability of the ruble and the operation of the payment system. Without the exceptional liquidity support, the economy could have experienced an even sharper contraction, which might have led to deflation, and the illiquidity could have disrupted the payments system. Also, the measures had a firm legal basis, either from existing laws and statutes or new legislation (unsecured lending, subordinated loans, the placement of deposits, lending against non-marketable assets and guarantees, and the partial guarantee of losses on interbank transactions). And market reports suggest that the CBR strengthened its credibility through this response.

- $\quad$ Transparency: Over the past 7-8 years, the CBR has made enormous progress in enhancing the transparency of its monetary operations, and now complies with all criteria under the Code of Monetary and Financial Policy Transparency. With clear disclosure of CBR policies, the liquidity support could guide expectations in the right direction, enhancing the effectiveness of the exceptional policies.

- Clear operational focus. The measures were designed to deal with the effects of the impaired market (the interbank market for liquidity), and included support directly to the interbank market as well as indirectly through loans and deposits to credit institutions to bypass the interbank market during the period of greatest stress. The CBR managed to avoid direct operations with non financial private sector, which helped minimize its credit risk.

- Good policy coordination. The CBR made a 5-year loan to the DIA and the government also provided liquidity support through the placement of its deposits and subordinated loans, as well as shifting to an expansionary fiscal stance. Since the CBR also supervises credit institutions, it could easily monitor the credit and other risks associated with the exceptional lending, and it placed resident supervisors in credit institutions that received unsecured loans.

- $\quad$ Risk management and limiting moral hazard. As the CBR widened its range of acceptable collateral, it took a number steps to strengthen its collateral management, including applying more stringent quality factors to loans in category 2 , limiting the maturity of loans against loan-book collateral to 90 days, and accepted foreign securities in the collateral pool. The central bank did add to its risk by introducing unsecured lending, accepting non-marketable collateral and guarantees, and providing partial guarantees of interbank transactions. As of April 2011, the overwhelming 
majority of liquidity operations have been repaid, with relatively minor losses, even though unsecured loans accounted for almost half of the ELA.

\section{Going forward, the CBR has made ELA a permanent feature of its institutional}

framework. In its guidelines for monetary policy for 2011-13, the CBR states that it stands ready to provide similar assistance if warranted by financial conditions, but provides no further details on how it might provide this assistance. A public disclosure of this intention is very sensible. Credit institutions will rightly expect the CBR to undertake a similar operation in the event of a crisis of similar severity, since this fits naturally into the CBR's mandate, and the central bank would damage its credibility by denying that this kind of operation would never happen again.

\section{Some countries announce clear policies on ELA, while others adopt a more ambiguous stance.}

- Canada. The Bank of Canada publishes an explicit statement of the legal authority and limits of the emergency lending operations. The statement distinguishes among a standing liquidity facility (overnight collateralized lending at a penalty interest rate to cover official settlement shortfalls), ELA (collateralized lending for up to 6 months to cover temporarily liquidity shortfalls in banks that supervisors deem to be solvent); and systemic risk financing (which allows for direct liquidity lending when the Bank of Canada is prepared to say publicly that there is a systemic risk).

- Norway. As another example, Norges Bank publishes its lender of last resort policy, which stipulates that the bank can provide emergency liquidity support to address threats to financial stability and that all emergency lending must be backed by sound collateral.

- $\quad$ United States. The U.S. Federal Reserve has not yet published any formal statement of how it will manage liquidity crises in the future, largely because the Dodd-Frank bill redistributed the responsibility for emergency lending between the Fed, the FDIC and the U.S. Treasury. Perhaps the new Financial Stability Oversight Council will clarify this issue, once the regulations have been approved that determine the exact allocation of these new responsibilities.

- United Kingdom. The Bank of England has issued a general statement indicating that, in exceptional circumstances, as part of its central banking functions, it acts as 'lender of last resort' to financial institutions in difficulty in order to prevent a loss of confidence spreading through the financial system as a whole. However, it weighs the public interest case for disclosure against the potential systemic consequences, and can decide to publicize the provision of liquidity assistance once it considers that the need for secrecy has ceased.

\section{The CBR needs to consider a few issues in incorporating ELA into its institutional framework:}


- Better risk management: The weak point of the emergency assistance was the decision to accept unsecured lending and non-marketable collateral and guarantees. Perhaps these operations were a realistic response to the scarcity of high quality collateral in Russia, but they exposed the CBR to considerable risk, even though resident supervisors were placed in banks receiving unsecured loans. In a future systemic crisis, it might be better to leave these high risk operations to the government, which has very low debt and the ability to adjust fiscal policy if necessary to absorb the losses.

Alternatively, the government could be required to guarantee any loan that is unsecured or backed by non-marketable collateral or guarantees. Otherwise, the central bank runs the risk of incurring large losses that could permanently weaken its capital and undermine its long-term credibility.

- Transparency. The CBR could weigh the relative benefits of its current stance on disclosure of ELA, which is similar to the Bank of England, versus a clearer ex ante statement of policy, as in the case of Canada. To further strengthen its credibility, the CBR might benefit from a clear public commitment to abide by certain rules to contain pressure for inappropriate and non-transparent actions. At the same time, it might want to retain the flexibility in deciding on the details of its response, given that all crises have many unique aspects. Moreover, the CBR might want also evaluate the benefits of ex-post disclosure of ELA operations by institution as a way to help ensure that the ELA is distributed among credit institutions according to objective criteria.

\section{Solvency Support}

\section{During the crisis, the Russian Government and the CBR provided capital to} strengthen the banking system. With the banking system under added pressure on account of deposit outflows and some bank failures, the public sector injected capital into banks. The Russian government shored up capital in several government-owned banks, including VTB (the second largest state-owned bank), mortgage and leasing companies, as well as to VEB. These capital injections amounted to Rub 505 billion (1.3 percent of GDP). Additional capital was provided to state and private banks (including Sberbank and VTB) from either VEB or the CBR in the form of subordinated loans, totaling Rub 904 billion (2.2 percent of GDP). In addition, the Government announced Rub 300 billion of guarantees of bank loans to key non-financial corporations.

38. From September 2008 onwards, the CBR and the MoF jointly made decisions to rescue six banks considered of systemic importance at the federal or regional level. ${ }^{25}$ These banks received solvency support from the CBR, via VEB or other banks such as CJSC Gazenergoprombank, OJSC Promsvyazbank and JSCB National Reserve Bank (OJSC). Such

\footnotetext{
${ }^{25}$ These banks were OJSC Yarsotsbank, OJSC Sobinbank, KIT Finance Investment Bank (OJSC), CJSC Globexbank, JSCB Rossiysky Capital (OJSC) and OJSC JSCB Svyaz-Bank.
} 
support allowed the banks to meet their obligations to creditors and depositors, stabilize their financial positions and maintain liquidity at appropriate levels. Two of these banks, KIT Finance and Rossisky Capital subsequently received further support from the DIA using the new powers provided under the AM Law.

39. The CBR also extended a five-year loan to the DIA to help fund measures aimed at supporting banks. After the AM Law was passed, the DIA provided financial support in the form of secured loans to the bank or an investor for a period of up to five years and purchase of assets from restructured banks. Apart from the loan from the CBR, the DIA used the Russian Federation's cash contribution of Rub 200 billion to provide financial support to new investors and to directly recapitalize banks. The DIA directly injected capital into six banks of which two were effectively nationalized by the DIA. The total amount of financing by the DIA (as at February 1, 2011) reached Rub 346 billion, including Rub 131 billion in loans from the CBR and Rub 215 billion in loans from the initial capital contribution of the Russian Federation to the DIA's capital. Of this amount, Rub 304 billion is outstanding and Rub 43 billion has been repaid in cash plus Rub 96 billion in assets and Rub 20 million in interest.

40. The solvency support measures were necessary to limit contagion risks and safeguard financial system stability. The framework for solvency support should allow the state (or an agency of the state) (i) to enter rapidly and in a legally robust manner into transactions that buttress the solvency of ailing banks (recapitalization, guarantees, etc.,) and (ii) to execute those transactions rapidly. ${ }^{26}$

41. To minimize moral hazard going forward, such solvency support should be complimented by a robust prompt remedial action framework and resolution framework. The provision of public financial support should also be accompanied by the attribution of losses first to the existing shareholders and then to unsecured creditors, as well as other measures to mitigate moral hazard such as the removal of the Board and senior management and restrictions placed upon compensation to management and payment of dividends to shareholders. Plans should also be put in place to secure new capital from shareholders with a clear exit strategy mapped out in advance for the official sector support.

42. The solvency support should also be provided by the Russian government rather than the CBR. The AM Law envisages that financial support can come from the DI Fund, the CBR (through a loan) and federal budget through a property contribution of the Russian Federation in the DIA's property (separate from the DI Fund). ${ }^{27}$ During the crisis, solvency support came from both the Russian Government and the CBR loan. With the plans to make

\footnotetext{
${ }^{26}$ See IMF, An Overview of the Legal, Institutional and Regulatory Framework for Bank Insolvency, 2009. (http://www.imf.org/external/np/pp/eng/2009/041709.pdf)

${ }^{27}$ AM Law Art 10
} 
the AM Law permanent, the possibility of support from these sources will remain. The mission recommends that in future, solvency support should come from the Russian government rather than the CBR. This is to protect the CBR from exposures to its balance sheet. If the CBR were to provide the solvency support, it should be backed by a guarantee from the government. Legislative amendments should be made to provide the legal underpinnings for the aforesaid solvency support.

\section{B. Orderly and Effective Resolution}

\section{Prior to the crisis, the authorities had limited tools available to deal with a}

failing bank. These included a mandatory freeze on banks taking new deposits and a mandatory revocation of the banking license for a bank with a CAR of less than 2 percent, or if a bank was unable to make mandatory payments for longer than fourteen days. As noted in the previous FSAP in 2007, these were neither sufficiently early nor effective to deal with failing banks in a way which would minimize contagion and financial stability risk as well as cost to the state.

44. Prior to the AM Law, the official administration powers were very limited. Under the pre-existing legislation, an official administrator may be appointed by the CBR when (i) the license is revoked ${ }^{28}$, (ii) when there is a violation of laws, rules and regulations ${ }^{29}$ or (iii) when the bank is unable to satisfy claims of creditors, unable to prevent its capital from being reduced by 30 percent, etc. ${ }^{30}$ In the first scenario, the administrator is appointed for the interim period after the withdrawal of the license and the time the arbitration court makes a decision on the bankruptcy of the bank or appointment of a liquidator. The administrator is appointed by the CBR to operate the bank during this interim period to protect the interests of creditors and depositors. In the latter two cases, the administrator may be appointed to manage the bank for a period of up to six months. During this period, the powers of the executive bodies shall be either limited or suspended. The administrator however does not have any restructuring powers to successfully resolve the bank, such as the ability to carry out a P\&A, and this use of the official administration powers has rarely been deployed.

45. As a result, like in other countries, the Russian authorities found themselves having to bail-out failing banks to minimize contagion. After having provided financial support to rescue six failed banks (see above), the authorities passed temporary legislation in October $2008^{31}$ to empower the DIA to restructure and resolve failing banks. The cost of these six resolutions and the emergence of other failing banks were cited by officials as

\footnotetext{
${ }^{28}$ BLaw Art. 20

${ }^{29}$ CBR Law Art. 74

${ }^{30}$ ILaw Art. 17

${ }^{31}$ AM Law, powers through 31 December 2011
} 
factors in passing the emergency legislation quickly. The authorities took official and wide ranging powers deployable at an early stage and with very flexible triggers determined by the CBR, if a failing bank presents a systemic risk and there exists evidence of the bank's unstable financial position or there is a threat to the legitimate interests of bank depositors and creditors. ${ }^{32}$ Under the AM Law, when a bank is considered by the DIA to be financially unstable, the CBR may invite the DIA to participate in rescue measures for the bank. The DIA then makes an assessment as to whether to participate and proposes an action plan, which is approved by the CBR and the Executive Board of the DIA. The DIA becomes appointed as an official administrator to carry out the action plan. The powers under the AM Law $^{33}$ allow the DIA to:

- $\quad$ Conduct an on-site audit, jointly with the CBR, when the CBR determines that it is necessary in light of the financial instability of a bank;

- $\quad$ Provide financial assistance to parties to acquire shares/ equity interest in a bank (investors);

- $\quad$ Provide financial assistance to a bank or banks to acquire all or parts of assets/ liabilities of the failing bank;

- $\quad$ Acquire shares/ equity interest in a failing bank;

- $\quad$ Organize auction sales of assets that are pledged as collateral for a bank's obligations;

- $\quad$ Perform functions of official administration including the ability to acquire assets of the bank or to undertake P\&A transactions involving an acquiring bank.

46. Since late 2008, the DIA and the CBR worked effectively in using these powers to resolve eighteen banks, considered systemically important either at a federal or regional level. Out of these eighteen banks, thirteen banks were sold to new investors, with financial support provided to the new investors by the DIA. In four of these cases, the DIA also directly acquired shares in the banks, and in two other cases the DIA became the full owner. The DIA is required to sell its shares in the bank when an investor subsequently becomes available and has managed to do so in four cases. It plans to merge the two banks it fully owns. The remaining three banks were resolved using P\&A transactions, with financial support from the DIA provided in the form of loans to the purchaser. ${ }^{34}$ The DIA considers P\&A to be a viable option only when the bank's deposit liabilities exceed US\$70 million, when the good assets constitute not less than 70-80 percent of the transferred assets, and this is the least costly option for the DI fund. One of the banks resolved using a P\&A was JSCB MZB (CJSC) which resulted in the purchase of the bank's assets and liabilities by Bank of

\footnotetext{
${ }^{32}$ AM Law Art 1

${ }^{33}$ AM Law Art 2

${ }^{34}$ Loans were to provide liquidity due to the mismatch between the maturity of liabilities and assets transferred.
} 
Moscow OJSC (BOM). In this case, the individual depositors and first priority creditors received their claims in full, household deposits continued to operate following the P\&A and shareholders sustained losses equal to their value of shares or equity contributions. However, the P\&A had to be made economically feasible by the DIA granting a loan of Rub 1.8 billion for a two year term to BOM, collateralized by the assets that were transferred to BOM. While this loan has since been fully repaid, BOM has subsequently been rescued by VTB bank.

\section{The measures were successful at maintaining financial stability but provided} support to some shareholders and uninsured creditors. Shareholders were only completely written off (or written down to 1 ruble) in nine of the eighteen bank resolutions, including the three P\&A transactions. In at least two cases, funds allocated by the DIA exceeded insured liabilities. While this experience was not by any means unique during the global crisis, a permanent regime should try and mitigate the moral hazard risks entailed.

48. On the basis of the crisis experience, the authorities plan to make the temporary legislation permanent when it expires in end-December 2011. However, the powers under this legislation apply only to systemic banks. This risks exacerbating moral hazard as it enshrines a resolution framework with a limited set of resolution tools with late triggers for non-systemic banks and a wide range of tools (which may be used to support the creditors of a failed bank) with early triggers for systemic banks, which are likely to be big banks. The mission's recommendations for a permanent resolution regime follow.

\section{Restructuring under Official Control}

49. A single, strengthened regime should be introduced for restructuring banks as a going concern under official administration. The existing provisions in the ILaw, BLaw, CBR Law and the proposed permanent legislation that deal with bank resolution should be streamlined and merged into a single piece of legislation providing for the DIA to be appointed as official administrator. Such a regime should include the following features:

- $\quad$ Triggers. The CBR should be able to appoint the DIA as an official administrator at a sufficiently early stage (before actual insolvency) for all banks, not just systemic ones, when one or more quantitative or qualitative triggers are breached. Examples of quantitative triggers are when capital or liquidity ratios below a fixed percentage of that is required by the regulator. Qualitative triggers might encompass a threat to financial stability; if the bank is or is likely to become insolvent; is engaging in an unsafe/unsound practice or there is a threat to the interests of depositors/creditors.

- Objectives and tasks. Once the official administrator is appointed, he should take over powers of all decision-making bodies of the bank and take over managerial control. He should have access to all relevant information and take control of the premises of the bank. His role is two-fold; (i) to assess the real financial situation of the bank, preserve asset values and establish a new balance sheet; and (ii) to design and implement a restructuring plan for the bank. In case restructuring is not an option, the official administrator should prepare the bank for orderly liquidation. 
- Restructuring tools. The official administrator should be empowered to use a range of restructuring tools, some of which currently exist in the AM Law. The decision on which tool to deploy or whether instead to liquidate the bank and pay out insured depositors should be taken on a least-cost basis. The toolkit should comprise of:

- rapid recapitalization of the bank without pre-emptive rights of existing shareholders $;^{35}$

- write down capital or convert subordinated debt into equity;

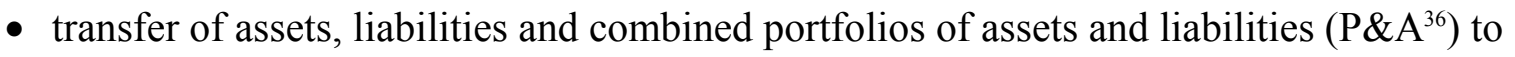
third party acquirers with the possible use of a bridge bank (see Box 1);

- merger with another bank;

- bank-debt restructuring (see Box 1).

\section{Box 1. Developing a Permanent Resolution Regime for Russia}

A review and rationalization of the various laws, tools, and triggers which form the bank resolution regime should be undertaken in the near future. The current framework, while appropriate in a crisis, risks exacerbating moral hazard. It enshrines a set of limited tools with late triggers for non-systemic banks and a set of flexible tools with early triggers for systemic banks, which are likely to be big banks. This is because the purchase and assumption (P\&A) powers under official administration can only be deployed for systemic institutions; and open bank assistance (OBA) in the form of loans (to the failing firm or purchaser), asset purchases, recapitalization with public funds, and nationalization can also be deployed for these institutions. International experience suggests that $\mathrm{P} \& \mathrm{~A}$ transactions are often cheaper than liquidation and payout; and that the risks of OBA are often underestimated, with costs usually higher as uninsured creditors are bailed out. The following reforms would address these concerns.

\begin{tabular}{|c|c|c|}
\hline Current regime & Resolution Tools & Recommendations \\
\hline $\begin{array}{c}\text { Only for bank } \\
\text { failures which } \\
\text { present a systemic } \\
\text { risk }\end{array}$ & Open bank assistance & $\begin{array}{c}\text { Only if a grave systemic risk is } \\
\text { identified by the Government }\end{array}$ \\
\cline { 2 - 3 } & $\begin{array}{c}\text { Official administration with } \\
\text { a restructuring toolkit } \\
\text { comprising P\&A and other } \\
\text { powers (which should be } \\
\text { selected on least cost basis) }\end{array}$ & $\begin{array}{c}\text { For all bank failures at } \\
\text { qualitative and early } \\
\text { quantitative pre-insolvency } \\
\text { triggers e.g. } 75 \% \text { or } 50 \% \text { of } \\
\text { minimum CAR }\end{array}$ \\
\hline For all bank failures & Liquidation and payout & For all bank failures \\
\hline
\end{tabular}

In addition, the authorities should consider a range of further measures and tools to mitigate the risk that OBA would need to be provided to systemic banks.

Recovery and Resolution Plans (RRPs): Also known as "living wills," RRPs can improve the resolvability of systemic institutions if used to identify measures the firm and the authorities should undertake in advance of a failure, to facilitate more effective and coordinated recovery or resolution. These should include ex ante measures the firm should take to strengthen its capital position, liquidity buffer, improve its information systems etc., and measures the authorities should take to strengthen early intervention and resolution preparedness and incentivize structural changes in the firm.

Bridge banks: Bridge banks can be an effective tool for dealing with failed banks. They offer the benefits of a P\&A transaction, which 'rescues' key liabilities (such as retail deposits) and good assets, while still allowing other creditors to absorb losses and giving the authorities more time to conduct a sale of the operations and assets of the bank. This tool should be added to the permanent bank resolution regime in Russia.

Bank debt restructuring: The international community is currently considering a range of contractual and mandatory tools and instruments which could be used to recapitalize a failing bank, without closing it. The Russian authorities should continue to follow developments and consider which aspects of the ultimate proposals from the BCBS and FSB should be adopted for Russian banks, particularly its systemic institutions, in the future. 
50. To mitigate the risks of moral hazard, there should be a stringent systemic risk test for OBA. OBA tools such as loans to purchasers and investors, capital injections, or nationalization should be restricted to only those cases that pose a grave systemic threat, with a clear process that entails a decision taken at a very high level by the government. ${ }^{37}$ Furthermore, in such circumstances, the DI fund can only contribute up to what it would have incurred in liquidation, with the remainder of the funds having to be provided by the government. Box 1 sets out the mission's proposal for developing a permanent resolution regime for Russia.

51. To better carry out its role as the official administrator, coordination between the DIA and the CBR can be improved. The DIA should be given more advanced notice before a license is revoked by the CBR, as well as the powers to conduct an audit of problem banks jointly with the CBR. ${ }^{38}$ A "watch-list" of problem banks should be created with banks assigned to the list based upon pre-agreed criteria. The DIA should be notified by the CBR of any banks which are placed, or which are reviewed for potential placement, on the list. ${ }^{39}$

52. The mission also supports some other proposals of the authorities to enhance the resolution framework. Some of the proposals have been included in the proposed legislation ${ }^{40}$ making the powers under the AM Law permanent while others are still being considered. The proposals include:

- $\quad$ Allowing the staff of DIA, and the institution itself to handle secret information.

- Improving the DIA's method for remote analysis of problem banks and identifying potential investors in problem banks.

- $\quad$ Allowing the transfer of a problem bank's assets and liabilities (P\&A) to more than one acquirer.

\section{Gone Concern Resolution: Orderly Liquidation}

53. The liquidation framework in Russia adequately addresses the financial stability concerns that are relevant to the liquidation of a bank. A liquidation framework for banks should recognize the unique features of banks (such as the need to protect deposits, lending and payment services) that call for special treatment during the insolvency process and allow

\footnotetext{
${ }^{37}$ In the US, the systemic risk exemption which in effect needs to be triggered before OBA can be provided by the FDIC, is an extraordinary procedure, requiring the approval of super majorities of the FDIC Board, the Federal Reserve Board, and the Secretary of the Treasury in consultation with the President.

${ }^{38}$ Under the Canadian framework, the OSFI informs the CDIC (deposit guarantee scheme) as at its earliest stage of supervisory measures. The OSFI sends intervention reports to the CIDC and holds joint meetings to discuss the risk profile of the institution.

${ }^{39}$ This could be partly based on the CAMELS classification groups of the CBR.

${ }^{40}$ Proposed legislation currently with the Russian Ministry of Justice
} 
for liquidating banks in an orderly manner. This involves rapidly transferring insured deposits (possibly combined with assets) and critical banking functions (payment services, trade finance) out of the insolvent estate before the remainder is liquidated in the traditional fashion. The liquidation framework for banks is set out in a specific insolvency law, the ILaw.

\section{Furthermore, the CBR is rightly involved in almost every stage of the liquidation}

process. The CBR's involvement in the liquidation process of banks is crucial as the CBR would have the information about the financial situation of the banks under liquidation. CBR's involvement will also allow it to feed financial stability concerns into the liquidation process. Although the insolvency process is subject to the arbitration court, the CBR's involvement is seen in the following areas:

- Upon revocation of a licence, the CBR has a duty to initiate liquidation proceedings. The CBR appoints an official administration to manage the bank in the interim period, headed by a CBR employee and may include employees of the DIA.

- $\quad$ The right to file a bankruptcy petition with the arbitration court belongs to the bank itself, its creditors, depositors as well as the CBR. The liquidator for a bank that has a licence to accept household deposits is the DIA. For other banks, court-appointed trustees that are accredited with the CBR as bankruptcy trustees for credit institutions are appointed as liquidators.

- In the conduct of liquidation proceedings, the CBR audits the activities of the liquidator of the bank, establishes the rules for the submission to the CBR of the reports of the institutions being liquidated, performs accreditation of court-appointed trustees with the $\mathrm{CBR}$, approves the interim liquidation balance sheets and the liquidation balance sheets and performs CBR payouts to depositors of banks that are declared bankrupt and are not participants in the DI scheme.

\section{Proposed amendments ${ }^{41}$ to the ILaw will further enhance the insolvency}

framework for banks. The mission supports the amendments which provide for, inter alia, non-cash settlements with creditors in the course of bankruptcy proceedings; prompt transfer of assets and liabilities of the bankrupt bank to an operational bank; defined procedures for the transfer of the balance assets after settlement with creditors to its shareholders; ensuring the safekeeping and integrity of information relating to a bank's property and liabilities; and imposing criminal liability on directors and management for falsification of accounts, statements and reports.

\footnotetext{
${ }^{41}$ Proposed legislation currently with the Russian Ministry of Justice.
} 


\section{Cross-Border Coordination}

56. Resolution is rendered more complex in the context of a banking group composed of multiple branches and subsidiaries across jurisdictions. As such, the framework for early intervention and resolution should reflect the fact that banks are increasingly part of larger, international groups. ${ }^{42}$

\section{The CBR has made extensive efforts in enhancing cross-border cooperation.}

- $\quad M o U s$. The CBR has entered into 32 bilateral MoUs and exchanged 2 letters of cooperation with foreign bank supervisors to achieve cooperation and information sharing between the banking supervisors of home and host countries to allow crossborder supervision of the activities of credit institutions. In the absence of a MoU, the CBR can cooperate with a foreign supervisor by addressing ad-hoc requests for information.

- $\quad$ Bilateral meetings. The CBR also engages in bilateral meetings with bank supervisors of the home countries of parent banks that have subsidiary lending institutions in the Russian Federation, as well as countries in which Russian banks have a commercial presence.

- $\quad$ Supervisory colleges. To coordinate the actions of supervisory authorities responsible for the supervision of the activities of cross-border establishments of banking groups, the CBR is also a member of five supervisory colleges, supervising the activities of cross-border credit institutions, created by the supervisory bodies that supervise the activities of parent banks. In relation to the supervision of Russian banks who have subsidiaries in foreign jurisdictions, the CBR has also formed a supervisory college for VTB bank.

58. However, the effectiveness of the efforts is impeded by restrictions on the type of information that can be shared. Specifically, banking secrecy provisions in the CBR Law as well as in the $\mathrm{BLaw}^{43}$ restrict the right to request and the right to provide information that relate to operations of credit organizations and their clients and require assurance by the corresponding supervisory body of the information safety (confidentiality) regime corresponding to the laws of the Russian Federation. Information concerning accounts and deposits or details of specific transactions or operations cannot be shared and the CBR and DIA can be held liable for the divulgence of banking secrets, including having to pay compensation for damage caused.

\footnotetext{
${ }^{42}$ See IMF, Resolution of Cross-Border Banks - A Proposed Framework for Enhanced Coordination, 2010, p. 25-27. (http://www.imf.org/external/np/pp/eng/2010/061110.pdf)

${ }^{43}$ CBR Law Art 51 and BLaw Art 26
} 
59. Proposed legislative amendments which will remove the restrictions on the sharing of information should be passed quickly. Legislative amendments are pending before the Duma to remove restrictions on the type of information that can be shared..$^{44}$ It is also noted that the amendments will allow on-site examinations of cross-border establishments (Russian subsidiaries of banks) by the home authority.

\section{Consideration could also be given to other mechanisms for enhancing cross-} border cooperation. One approach would be to introduce mechanisms for the mutual recognition of decisions made in other jurisdictions in the context of insolvency or reorganization proceedings, subject to conditions such as non-discriminatory treatment of foreign creditors and reciprocity. ${ }^{45}$ Another mechanism would be ex ante burden sharing arrangements. ${ }^{46}$ Such agreements can enable the relevant home and host authorities to act quickly during a crisis and avoid protracted negotiations, but not to an extent that it implicitly cedes sovereign rights and compromises domestic depositors and creditors. ${ }^{47}$

\section{Deposit Guarantee Scheme}

61. The legal framework for the DI scheme appears to be well structured and this has been borne out by the experience of the DIA during the crisis. The purpose of the DI scheme is to protect the rights and legitimate interests of household depositors with banks of the Russian Federation, strengthen public confidence in the banking system and encourage household savings in the banking system. The participation of the banks in the deposit insurance scheme is mandatory for all banks who accept household deposits. ${ }^{48}$

\section{The DIA has had extensive experience in relation to its role as the pay-out} agency, having made pay-outs to insured depositors in more than fifty cases during the crisis. A payout is triggered upon revocation of a bank's license by the CBR or imposition of a moratorium by the CBR on honoring the claims of bank's creditors. ${ }^{49}$ In practice, the DIA has access to the relevant data and is able to pay the depositors promptly. During the crisis, the payout is achieved within a short time of seven to fourteen days after the closure of the bank and receipt of depositor's claims. The coverage is now 100 percent of total deposits per

\footnotetext{
${ }^{44}$ See draft amendment to Art 51 of the BLaw

${ }^{45}$ See Basel Committee on Banking Supervision, Report and Recommendations of the Cross-Border Bank Resolution Group, March 2010.

${ }^{46}$ The Nordic-Baltic Stability Group recently entered into an MoU on burden-sharing.

${ }^{47}$ See IMF, Resolution of Cross-Border Banks - A Proposed Framework for Enhanced Coordination, 2010, p. 23 - 25, (http://www.imf.org/external/np/pp/eng/2010/061110.pdf)

${ }^{48}$ The Board of the DIA comprises officials from the MoF, CBR, President's Office, Ministry of Economic Development, and the Federal tax service.

${ }^{49}$ DI Law Art 8
} 
depositor with a bank, net of liabilities, up to a maximum of Rub 700,000..$^{50}$ This coverage works out to be about 2.2 percent of per capita GDP (assuming gross payout), which is in line with international deposit insurance average levels of about two times per capita GDP. However, compared to an alternative metric which seeks to balance protection of small depositors with moral hazard, it is high. This metric would aim for full protection for approximately 80 percent of depositors but only 20 percent of deposits by value, whereas the Russian deposit insurance fully covers 99 percent of retail deposits by number and about 70 percent of retail deposits by value..$^{51}$

\section{Ex Ante Funding}

63. The DI scheme is funded by ex ante contributions from an initial contribution of the government and quarterly premiums paid by member banks. The fund obtained an initial property contribution of Rub 2 billion from the Russian Federation and premiums are paid by member banks quarterly on the basis of a uniform flat rate. The rate of insurance premiums is set by the DIA's Board of Directors. The maximum rate of the insurance premium was reduced from a flat rate of 0.15 percent of insured deposits to 0.1 percent in September 2008. As at January 1, 2011, the fund stands at Rub 122.7 billion, about 4.4 percent of total covered deposits excluding Sberbank, or 1.8 percent including Sberbank. While the mission has not undertaken a detailed assessment of coverage, we would suggest building up the fund to a target of approximately 2-3 percent including Sberbank, or approximately 5-6 percent excluding Sberbank. In case of a deficit in the fund, the premium can be increased for two quarters during an eighteen month period to 0.3 percent per quarter. There are also provisions for funding from the Reserve (Stabilization) Fund or the federal budget if there is a shortfall..$^{52}$

\section{Depositor Preference}

\section{The DIA, through subrogation, is given a high ranking priority right over the} estate of the failed bank as part of the pool of first priority creditors. Depositor preference is provided for under the DI law and the ILaw. After reimbursing a depositor, the DIA subrogates the depositor's claims against the bank and such claims shall be satisfied as first priority creditor claims ${ }^{53}$ in the course of bankruptcy proceedings. The immediate effect of such a priority right is to protect the contributing banks and ultimately the public purse against the cost of deposit insurance. By providing a mechanism for recovering the pay-outs

\footnotetext{
${ }^{50}$ Since 2005 the deposit insurance coverage was increased in steps from 100,000 rubles to 700,000 thousand rubles in October 2008, when co-insurance was also abolished in October 2008.

${ }^{51}$ See pages14-15 of "the Design and Implementation of Deposit Insurance Systems" (D. Hoelscher, M. Taylor and U. Klueh, 2006).

${ }^{52}$ DI Law Art 41

${ }^{53}$ DI Law Art 13 and ILaw Art 36
} 
from the assets of the estate, the priority right minimizes the final cost of the insurance, the possibility of shortfalls, and ultimately the need for official support and topping up by the other banks.

\section{Use of DI Funds as Bank Restructuring Tool}

65. There is also a possibility of using the DI fund to assist in bank resolution, such as a P\&A transaction. However, this is provided that it is the least-cost option when compared to the amount that would have been paid out under the DI fund in case of the liquidation of the bank and if the soundness of the fund is not affected ${ }^{54}$. If the size of insured liabilities passed to an acquirer exceeds the value of the assets transferred (negative transfer balance), the DIA shall use the DI Fund to make up the difference minus any premium paid by the purchaser. This contribution from the DI Fund can be recovered in the liquidation of the bank and satisfied among creditors of the first run.

\section{During the crisis, the DIA did not need to use the DI fund as a bank} restructuring tool. The funds used during the crisis were either from investors, the CBR or the Federal Budget. ${ }^{55}$ It is important to ensure that if DI funds are used, it should be on the basis of the least cost option and the funds should not exceed what would have been paid out in a liquidation of the bank.

\section{Co-insurance}

67. The CBR has expressed concerns about the impact that the high coverage limit is having upon competition and is considering whether co-insurance should be reintroduced to address these moral hazard concerns. Co-insurance is the use of a "deductible" so that insured depositors bear part of the risk of loss (e.g., 90 percent coverage).

68. In light of international experience, the mission recommends that the Russian authorities refrain from re-introducing co-insurance into the DI scheme. Recent country experience has shown that depositors will run even when a relatively small portion of their deposits are at risk.

- In the United Kingdom, the authorities concluded that a significant factor in the queues which formed outside Northern Rock was due to retail depositors 'running' and withdrawing even small deposits to receive 100 percent rather than lose the "coinsurance". For this reason, the United Kingdom's parliamentary committee concluded that:

\footnotetext{
${ }^{54}$ AM Law Art 10.

${ }^{55}$ However, the DI Fund would presumably have been exposed to losses if its recoveries had proven insufficient to repay the $\mathrm{CBR}$ loans.
} 
"The presence of an element of co-insurance in a deposit protection scheme adds considerable complexity for customers to understand: Northern Rock pointed to the difficulty of explaining the scheme's intricacies to their customers when the bank run occurred. Not only does co-insurance add complexity, it also does not work. Coinsurance implies that a potential depositor would have the means, time and ability to assess the financial strength of an institution through the examination of publiclyavailable information about that company. We do not believe this to be a realistic proposition." ${ }^{56}$

- $\quad$ The European Commission required all EU countries to remove co-insurance from their deposit insurance schemes.

The moral hazard risks could be managed by not increasing the Rub 700,000 coverage for an extended period of time and allowing inflation to slowly reduce coverage over time to a level closer to the 80:20 metric discussed above.

\section{Mandatory ban on deposit taking}

69. The mission notes that the mandatory ban that is triggered under the DI Law may cause hardship and recommends that this ban be revisited. Under the DI Law ${ }^{57}$, a bank is perceived as not complying with the requirements of membership in the DI scheme if, for six consecutive months, it does not comply with particular mandatory ratios established by the CBR in relation to, amongst others, its profits. This would trigger a ban on accepting household deposits and opening of bank accounts for individuals. Such a ban may cause difficulties, for example at banks which make small losses for a longer period but which otherwise would not fail and which do not represent a risk to depositor interests, and this may have unintended consequences on financial stability. While there is a moratorium currently in force, it expires in July 2011. The mission recommends that this issue of an automatic mandatory ban should be revisited promptly to ensure that there are good reasons for the ban to kick-in. It is noted that there is a draft law before the Duma to consider making the moratorium permanent. If the moratorium is not made permanent, it would be desirable to revise the relevant directive to allow more discretion to the relevant agency such as the CBR or the DIA to assess the underlying reasons for the non-compliance with the various financial ratios and take action commensurate with the risk to depositor interests.

\section{Other recommended reforms}

70. In addition, the mission recommends a number of other changes to enhance the deposit insurance scheme.

\footnotetext{
${ }^{56}$ See: http://www.publications.parliament.uk/pa/cm200708/cmselect/cmtreasy/56/5602.htm

${ }^{57}$ DI Law Arts $44 \& 48$.
} 
- $\quad$ Coverage: The mission notes that the CBR and the DIA are reviewing whether deposit insurance coverage should be extended to individual unincorporated entrepreneurs. Small entrepreneurs play an important role in the economy and need quick access to the working capital to continue trading in the event of a bank failure. The mission recommends extending coverage to such depositors.

- $\quad$ Gross vs. Net: The mission also recommends that in the future, once the coverage has declined in real terms, the authorities consider paying out retail depositors on a gross rather than net basis. Accelerating the repayment of outstanding customer loans penalizes customers who decide to borrow from the same bank where they hold their retail deposits. While we understand from the DIA that the extra complication of computing the net amount in the insurance determination does not unduly slow down the insurance payout (DIA staff reported that it added an extra day or so), paying out insurance on a net basis creates an incentive for borrowing customers to withdraw their retail deposits as needed to make day-to-day payments, creating an undesirable incentive for a deposit run to develop. Deposits should however still be allowed to be offset against any past-due and non-performing loans.

- $\quad$ Enforcement powers: The DIA does not have meaningful enforcement powers under the DI Law. If a bank violates any provisions of the DI Law, the DIA has to request the CBR to impose sanctions on the bank. ${ }^{58}$ The mission recommends that the DIA be given direct enforcement powers e.g. the power to issue directions or to impose fines for breaches of the provisions of the DI Law.

\section{Legal Protection}

\section{A strong crisis management framework should include provisions which} sufficiently protect the agencies such as the CBR, DIA and the MoF as well as its employees in the employment of the respective tools to address the crisis. Employees of supervisory agencies should be able to exercise their professional judgment and take the necessary action where the circumstances require, and should not be inhibited by the threat of lawsuits against their actions. In the context of crisis management, liability may occur when the supervisory authority failed to take any action notwithstanding the knowledge of serious problems in the bank, when measures were inadequate in response to the problems or when a shareholder of a bank challenges the appointment of an official administrator or certain restructuring measures. Hence, it is important that liability should accrue only in the event of gross negligence or willful misconduct on the part of the supervisory agency or its employees. This could help clarify in advance to potential plaintiffs that a case would have no chance of success, unless based on criminal activity, gross negligence or bad faith.

\footnotetext{
${ }^{58}$ Article 15(2)(4) DI Law.
} 
72. Russian legislation does not explicitly provide for legal protection against civil suits for supervisory agencies and their employees. On the contrary, Russian legislation explicitly provides that action can be taken against supervisory agencies. Article 50 of the CBR law provides that the CBR shall bear responsibility for its actions. Art 20 of ILaw provides that the interim official administrator can be liable if he fails to or improperly performs his duties. Art 25 of ILaw provides that shareholders who overall hold no less than 1percent of authorized capital can claim with the arbitration court against the CBR for damages caused by an unjustified institution of official administration. Article 15 of the Civil Code of the Russian Federation provides that a credit organization may claim compensation for loss, including damages caused by the CBR or its officials in the implementation of their supervisory duties.

73. The Russian Civil Code requires civil action to be taken against the entity and not the individual employees. The Russian Civil Code provides that a legal entity or an individual shall redress the injury inflicted by the employee during the performance of labour (official) duties ${ }^{59}$. The Russian Civil Code further provides that injury inflicted by State and local self-government bodies and their officials, including as a result of the issuance of an act of a state or self-government body inconsistent with the law or any other legal act, shall be subject to redress at the expense of the state treasury of the Russian Federation or the respective subject of the Russian Federation ${ }^{60}$.

\section{The agency can however recover losses from the employee in certain} circumstances. To ensure that employees do not abuse this immunity by taking actions that are contrary to the interest of the agency, the agency should be able to recover losses from the employee if a sufficiently high threshold has been breached, such as gross negligence or willful action. In this regard, Russian legislation provides for such recovery. Pursuant to paragraph 1 of Article 1081 of the Civil Code, a person compensated for the loss caused by another person (an employee or officer), has a right of recourse to that person. Under Article 238 of the Labour Code of the Russian Federation, the employee must reimburse to the employer the direct actual loss caused to the employer.

75. In line with BCP and international best practices, the mission recommends that civil liability should accrue only in the event of gross negligence or willful misconduct on the part of the supervisory agency or its employees. Box 2 sets out the BCP principles and specific country examples.

\footnotetext{
${ }^{59}$ Russian Civil Code Article 1068.

${ }^{60}$ Russian Civil Code Article 1069.
} 


\section{Box 2: Legal Protection Principles and Country Examples}

- $\quad$ Principle 1 of the $B C P$ provides that there should be legal protection for supervisors and the essential criteria elaborated in the Core Principles Methodology provides for protection to the supervisory authority and its staff against lawsuits for actions taken and/or omissions made while discharging their duties in good faith. The supervisory authority and its staff should also be adequately protected against the costs of defending their actions and/or omissions made while discharging their duties in good faith.

- In Belgium ${ }^{1}$, the law provides that supervisory bodies and personnel shall not be liable for any decision, act or behavior in the exercise of their statutory tasks, except in the event of fraud or gross negligence.

- $\quad$ In the United Kingdom ${ }^{2}$, neither the Bank of England nor any of its staff members or board members can be held liable for any act or negligence in discharging the BOE's statutory duties, unless it appears that the act or omission was done in bad faith. This is also the position in Ireland ${ }^{3}$.

- In $\quad$ Luxembourg ${ }^{4}$, supervisory authorities can only be held liable if the damages incurred are caused by gross negligence in the choice of and use of the methods deployed for the exercise by the authority of its public duty.

- In Singapore ${ }^{5}$, the Monetary Authority of Singapore, its directors, officers and employees are protected against actions, suits or other legal proceedings for acts done or omissions made in good faith.

1 Article 68 of the Law of 2 August 2002 on Financial Services

2 Banking Act 1987

3 Section 25A Central Bank of Ireland Act 1997

4 Article 20 of Law of 23 December 1998

5 Section 22 of the Monetary Authority of Singapore Act 
ApPendix I. An Illustrative EXample of a Prompt Remedial ACtion Framework

\begin{tabular}{|c|c|c|c|}
\hline & Triggers & Compulsory & Discretionary \\
\hline $\begin{array}{l}\text { Adequately } \\
\text { capitalized }\end{array}$ & $\begin{array}{l}\text { Groups } 4 \text { or } 5 \\
\text { but CAR > } \\
10 \text { percent. }\end{array}$ & $\begin{array}{l}\text { No capital distribution or } \\
\text { payment of management } \\
\text { fees which would cause } \\
\text { capital to fall below } \\
10 \text { percent. }\end{array}$ & \\
\hline Undercapitalized & $\begin{array}{l}8 \text { percent }< \\
\text { CAR }<10 \\
\text { percent }\end{array}$ & $\begin{array}{l}\text { 1. Capital distributions and } \\
\text { management fees } \\
\text { suspended } \\
\text { 2. Financial rehabilitation } \\
\text { plan required } \\
\text { 3. Prior approval for new } \\
\text { branches, acquisitions, } \\
\text { new lines of business }\end{array}$ & \begin{tabular}{|ll}
1. & $\begin{array}{l}\text { Require recapitalization by } \\
\text { issuing capital or selling to } \\
\text { another firm }\end{array}$ \\
2. & $\begin{array}{l}\text { Restricting transactions with } \\
\text { affiliates }\end{array}$ \\
3. & $\begin{array}{l}\text { Restricting rates on new } \\
\text { deposits }\end{array}$ \\
4. & $\begin{array}{l}\text { Restrict for a period of up to } \\
\text { six months certain } \\
\text { operations carried out by } \\
\text { credit organizations }\end{array}$ \\
5. & Restrict asset growth
\end{tabular} \\
\hline $\begin{array}{l}\text { Significantly } \\
\text { undercapitalized }\end{array}$ & $\begin{array}{l}4 \text { percent }< \\
\text { CAR < } 8 \\
\text { percent }\end{array}$ & $\begin{array}{l}\text { 1. Same as } \\
\text { undercapitalized } \\
\text { 2. Financial restructuring } \\
\text { plan required. } \\
\text { 3. At least two of the five } \\
\text { discretionary provisions } \\
\text { under Undercapitalized } \\
\text { including (1). }\end{array}$ & \begin{tabular}{|l} 
All of the above and: \\
6. $\begin{array}{l}\text { Replace managers of the } \\
\text { bank }\end{array}$ \\
7. $\begin{array}{l}\text { Penalties on } \\
\text { managers/directors }\end{array}$ \\
8. $\begin{array}{l}\text { Ban the opening of new } \\
\text { branches for a year }\end{array}$ \\
9. $\begin{array}{l}\text { Power to appoint a official } \\
\text { administrator if CAR falls to } \\
\text { e.g. } 7.5 \text { to } 5 \text { percent, } \\
\text { including powers to } \\
\text { undertake a P\&A, and to } \\
\text { revoke license } \\
\text { 10. Ban for a term of up to one } \\
\text { year banking operations of } \\
\text { the credit organization } \\
\text { which are permitted under } \\
\text { the issued license }\end{array}$ \\
\end{tabular} \\
\hline $\begin{array}{l}\text { Critically } \\
\text { undercapitalized }\end{array}$ & $\begin{array}{l}2 \text { percent }< \\
\text { CAR }<4 \\
\text { percent }\end{array}$ & $\begin{array}{l}\text { 1. Same as significantly } \\
\text { undercapitalized. } \\
\text { 2. Penalize managers and/ } \\
\text { or restrict compensation } \\
\text { of management } \\
\text { 3. Prohibit payments on } \\
\text { subordinated debt } \\
\text { 4. Require appointment of } \\
\text { official administrator } \\
\text { within } 90 \text { days }\end{array}$ & All of the above \\
\hline Closed & $\begin{array}{l}\mathrm{CAR} \leq 2 \\
\text { percent }\end{array}$ & $\begin{array}{l}\text { Withdrawal of the license } \\
\text { for banking operations. }\end{array}$ & \\
\hline
\end{tabular}

Many of these powers are available under the CBR Law, BLaw, ILaw and AM Law. The proposed reform is to encompass them, along with other measures, in a consolidated corrective action regime with a stepped scale of mandatory and discretionary actions by the supervisory authority. 


\section{Appendix II. Timeline of Crisis Related Policy Measures}

\begin{tabular}{|c|c|c|c|}
\hline Date & Measure & Comments & Status \\
\hline Aug-08 & Increase in CBR collateralized lending (repos, lombard loans, credit against untraded collateral) & $\begin{array}{l}\text { The volume of repo credits peaked at around } 750 \mathrm{bn} \\
\text { in January } 2009 \text {, and then declined rapidly. At end- } \\
2010 \text {, outstanding repos were about zero. }\end{array}$ & Repaid \\
\hline \multirow[t]{7}{*}{ Sep-08 } & \multicolumn{3}{|c|}{ Lowering of selected nonprimary CBR policy rates (minimum auction repo and refinancing rates unchanged) } \\
\hline & Lowering of reserve requirements & $\begin{array}{l}\text { RR were lowered from } 8.5 \text { percent for liabilities to } \\
\text { corporate nonresidents and } 5.5 \text { percent for other } \\
\text { liabilities in September } 2008 \text {, to a flat rate } 0.5 \\
\text { percent in October 2008. From May, } 2009 \text { RR were } \\
\text { gradually raised again. }\end{array}$ & $\begin{array}{l}\text { Largely } \\
\text { reversed }\end{array}$ \\
\hline & CBR intervenes to support the ruble in the face of large-scale capital flight & $\begin{array}{l}\text { Large scale foreign exchange sales continued though } \\
\text { january } 2009 .\end{array}$ & Ended \\
\hline & Short selling and margin trading suspended at stock market & & $\begin{array}{l}\text { Largely } \\
\text { ended }\end{array}$ \\
\hline & Unsecured CBR deposits provided to VEB and state banks to purchase four failing banks & VEB received RUB $260 \mathrm{bn}$ in deposits from CBR. & In effect \\
\hline & Increase in limits for deposit auctions by the Ministry of Finance for 2008 & $\begin{array}{l}\text { Depositing limits were increased from RUR } 625 \\
\text { billion to RUR } 1.55 \text { trillion. However actual } \\
\text { placement only reached a maximum of } 874 \text { billion } \\
\text { Rubles (on October 22). }\end{array}$ & Ended \\
\hline & Elimination of haircuts for OFZ and OBR collateral used for REPO auctions & & $\begin{array}{l}\text { partly } \\
\text { reversed }\end{array}$ \\
\hline \multirow[t]{6}{*}{ Oct-08 } & Introduction by CBR of uncollateralized-lending facility & $\begin{array}{l}\text { Lending under this facility peaked at close to ruble } 2 \\
\text { trillion in February 2009, and all loans were repaid by } \\
\text { end- } 2010 \text {. }\end{array}$ & Repaid \\
\hline & Phasing of quarterly VAT payments allowed over a 3-month period, to reduce liquidity squeeze & & In effect \\
\hline & Lowering bank contributions to the deposit insurance system & & In effect \\
\hline & Deposit insurance cover increased from Rub 400,000 to Rub 700,000, coinsurance abolished & & In effect \\
\hline & Powers of DIA are temporarily extended, inter alia allowing it to restructure problem banks & $\begin{array}{l}\text { Powers were given to the CBR/DIA to intervene early } \\
\text { in case of a systemic threat and apply a range of } \\
\text { tools including financing new investors, } \\
\text { nationalization, and transferring assets and liabilities. }\end{array}$ & $\begin{array}{l}\text { Law to } \\
\text { expire by } \\
\text { end-2011 }\end{array}$ \\
\hline & DIA receives capital injection from the $\mathrm{MoF}$ and access to uncollateralized CBR credit & & In effect \\
\hline
\end{tabular}




\section{Appendix II. Timeline of Crisis Related Policy Measures (CONTINUed)}

\begin{tabular}{|c|c|c|c|}
\hline Date & Measure & Comments & Status \\
\hline & CBR guarantees interbank transactions, if counterparty's licence is revoked & $\begin{array}{l}\text { During October-November } 2008 \text { the CBR concluded } \\
\text { agreements with } 17 \text { banks and VEB. }\end{array}$ & $\begin{array}{l}\text { Expired } \\
\text { End-2010 }\end{array}$ \\
\hline & Several banks are resolved via intervention from the Deposit Insurance Agency & & Done \\
\hline & Moratorium on DIA provisions obliging members to meet minimum capital and profitability standards & & $\begin{array}{l}\text { To expire } \\
\text { July } 2011\end{array}$ \\
\hline & Recapitalization of VEB to help it support the financial system & $\begin{array}{l}\text { VEB received ruble } 450 \mathrm{bn} \text { in } 10 \text {-year deposits from } \\
\text { the NWF, as well as a ruble } 175 \mathrm{bn} \text { "stock market } \\
\text { stabilization deposit." }\end{array}$ & in effect \\
\hline & Recapitalization of Sberbank (by CBR) & $\begin{array}{l}\text { Sberbank receives Rub } 500 \text { of subordinated loans for } \\
\text { a term of } 10 \text { years at } 8 \% \text { p.a. }\end{array}$ & $\begin{array}{l}\text { Partially } \\
\text { repaid }\end{array}$ \\
\hline & Provision of capital to banks by CBR and VEB through 5-11 year subordinated loans & $\begin{array}{l}\text { Beneficiaries included Sberbank and VTB, among } \\
\text { other banks. }\end{array}$ & Ended \\
\hline & Extension of the REPO facility to low-rated banks (category 4 and 5) on a case-by-case basis & & In effect \\
\hline & VEB purchases shares and bonds issued by Russian companies & Placements totaled Rub $129.4 \mathrm{bn}$ as of 12-1-2009 & Ended \\
\hline \multirow[t]{3}{*}{ Nov-08 } & Increase in key policy rates to stem capital flight & $\begin{array}{l}\text { The CBR refinancing rate was raised stepwise from } \\
11 \text { percent in August 2008, to } 13 \text { percent january } \\
2009 \text {. From, April 2009, rates were gradually } \\
\text { lowered again. }\end{array}$ & Undone \\
\hline & Start of gradual ruble devaluation (through january 2010) & $\begin{array}{l}\text { The ruble was allowed to depreciate by } 30 \text { percent } \\
\text { between Nov } 2008 \text { and Jan } 2009 \text {. }\end{array}$ & \\
\hline & Recapitalization of State Mortgage Agency (by MoF) & & Done \\
\hline \multirow[t]{2}{*}{ Dec-08 } & Extension of max. maturities to up to 12 months for repos, lombard, and untraded-collateral credits. & & $\begin{array}{l}\text { Largely } \\
\text { reversed }\end{array}$ \\
\hline & Relaxation of provisioning requirements & & $\begin{array}{l}\text { Partly } \\
\text { reversed }\end{array}$ \\
\hline \multirow[t]{2}{*}{ Feb-09 } & Relaxation of CBR collateral requirements & & $\begin{array}{l}\text { Partly } \\
\text { reversed }\end{array}$ \\
\hline & Start of gradual reduction of policy interest rates & $\begin{array}{l}\text { From April } 2009 \text { through May 2010, the refinancing } \\
\text { rate was lowered from } 13 \text { percent to a low of } 7.75\end{array}$ & $\begin{array}{l}\text { Partly } \\
\text { undone }\end{array}$ \\
\hline Jul-09 & Introduction of possibility for recapitalization of banks by MoF via injection of OFZs & The possibility has not been used. & n.a. \\
\hline
\end{tabular}


